\title{
Sosialisasi Pemanfaatan Jambu Air Menjadi Nata De Syzygium
}

\author{
Ermina Sari*1, Jumiati ${ }^{2}$, Sri Wahyuni ${ }^{3}$ \\ 1,2,3Universitas Lancang Kuning \\ Program Studi Pendidikan Biologi, Fakultas Keguruan dan Ilmu Pendidikan, Universitas Lancang Kuning

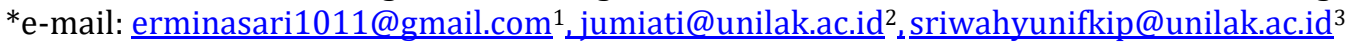

\begin{abstract}
Guava is one type of plant that is widely planted in a home yard environment. With the taste of guava that is slightly sour to sweet and its benefits are rich in vitamins and trees that can be used as a shade making it a favorite type to plant. Society in Perum. Lancang Kuning Sejahtera and Villa Padma have guava plants in the yard of the house that have not been utilized optimally. One of the economic use of guava is to make nata from it's fruit. Through Community Service activities, participants were given a socialization about the use of guava into nata de syzygium. The results of this activities are known to have increased public knowledge regarding the use of guava to become nata de syzygium. The mean pretest value is 19.99 or $20 \%$ and the average posttest value is 100 or $100 \%$.
\end{abstract}

Keywords: guava, nata, syzygium

\section{Abstrak}

Jambu air adalah salah satu jenis tumbuhan yang banyak ditanam di lingkungan pekarangan rumah. Dengan cita rasa jambu air yang sedikit sepat hingga manis dan manfaatnya yang kaya akan vitamin serta pohonnya yang dapat dijadikan peneduh menjadikannya jenis favorit untuk ditanam. Masyarakat di Perum. Lancang Kuning Sejahtera dan Villa Padma memiliki tanaman jambu air di pekarangan rumah yang belum termanfaatkan secara optimal. Salah satu pemanfaatan jambu air yang bernilai ekonomis adalah dengan membuat nata dari buah jambu air. Melalui kegiatan Pengabdian Kepada Masyarakat, peserta diberikan sosialisasi tentang pemanfaatan jambu air menjadi nata de syzigium. Hasil kegiatan Pengabdian Kepada Masyarakat yang telah dilakukan diketahui terjadi peningkatan pengetahuan masyarakat mengenai pemanfaatan jambu air menjadi nata de syzigium. Rerata nilai pretest adalah 19,99 atau $20 \%$ dan rerata nilai posttest adalah 100 atau $100 \%$.

Kata kunci: jambu air, nata, syzygium

\section{PENDAHULUAN}

Jambu air adalah salah satu jenis tumbuhan yang banyak ditanam di lingkungan pekarangan rumah. Jambu air memiliki banyak variasi jenis dan pembudidayaan. Ada banyak jenis jambu air yang mulai dibudidayakan seperti, jambu madu, jambu citra, jambu king rose, dan jambu lokal. Pembudidayaan jambu air pun bervariasi, mulai dari ditanam di pekarangan rumah hingga pembudidayaan dalam pot. Dengan cita rasa jambu air yang sedikit sepat hingga manis dan manfaatnya yang kaya akan vitamin serta pohonnya yang dapat dijadikan peneduh menjadikannya jenis favorit untuk ditanam.

Jenis jambu air yang banyak ditanam yaitu Syzygium aquaeum (jambu air kecil) dan Syzygium samarangense (jambu air besar). Jambu citra yang berasal dari daerah Demak adalah yang paling diminati masyarakat, karena buahnya besar dan perawatan tanamannya mudah (Hanifa dan Haryanti, 2016). Dari berbagai macam buah-buahan yang ada di Indonesia, jambu air adalah salah satu tanaman yang tidak terlalu sulit dalam pemeliharaanya. Tanaman jambu air mampu tumbuh di hampir semua tempat di Indonesia. Tanaman ini pun mudah menyesuaikan diri dengan segala jenis tanah asalkan tanah itu subur, gembur dan berair banyak. Keistimewaan lain dari tanaman jambu air adalah mudah didapat, tidak memerlukan perawatan yang terlalu mahal, buahnya sering bermunculan sepanjang tahun dan sosok tanamannya sangat teduh (Hariyanto, 1992).

Ukuran tinggi pohon jambu air lokal sekitar 4-5 meter dengan tajuk sekitar 2 meter. Pohon ini rimbun dan relatif pendek dibandingkan jenis jambu air lainnya. Bentuk batang pohon jambu bulat, permukaannya halus berwarna coklat dan bercabang-cabang. Daun-daunnya 
berbentuk tombak memanjang dengan perbandingan panjang dan lebar daun sekitar 3:2. Warna daun muda merah keunguan atau merah kecoklatan sedangkan saat tua berwarna hijau. Bunga jambu air bertipe spatula dengan warna mahkota kuning muda. Buah jambu berbentuk lonceng tak berlekuk sekitar 1-12 buah per tandan. Keunggulan pohon jambu air lainnya adalah memiliki ketahanan terhadap hama penyakit tanaman seperti jamur daun, penggerek batang, dan ulat pemakan daun. Ciri-ciri buah jambu air siap dipanen antara lain: ukuran buah sudah maksimum (besar), struktur daging buah empuk, dan warna kulit buah berubah dari hijau menjadi kemerahan tergantung varietasnya (Rukmana, 1997). Kelemahan yang paling mencolok dari buah jambu air adalah kulitnya yang mudah lecet dan kesegaran buah yang hanya bertahan sampai 3 hari (Tirtawanata,1999).

Dalam hal budidaya jambu air, perawatan bibit tanaman jambu air tergolong sangat mudah. Pohon jambu air mempunyai tingkat produksi buah yang lumayan tinggi, dalam keadaan yang optimal, satu pohon jambu air mampu menghasilkan buah sekitar 80-100 kg per tahun. Untuk menghasilkan buah jambu air berkualitas baik dengan rasa yang super manis, sebaiknya waktu panen dilaksanakan pada musim kemarau, hal ini disebabkan karena rasanya lebih manis sehingga waktu yang paling baik untuk memanen buah jambu adalah pada saat kemarau.

Perumahan Umum Lancang Kuning Sejahtera (LKS) dan Villa Padma adalah salah satu perumahan yang ada di Kecamatan Rumbai, Kotamadya Pekanbaru (Wahyuni, Sari, \& Afidah, 2017). Masyarakat di Perum. Lancang Kuning Sejahtera (LKS) dan Villa Padma Kel. Umban Sari, Kec. Rumbai banyak yang menanam tanaman jambu air di pekarangan rumah. Masyarakat memanfaatkan buah jambu air hanya sebatas untuk konsumsi pribadi saja. Selain itu, pohon jambu air dapat menjadi peneduh pekarangan rumah. Namun, masa panen jambu air yang singkat menyebabkan buah jambu air banyak yang jatuh, busuk, dan tidak dimanfaatkan oleh kebanyakan masyarakat. Buah jambu air dibiarkan terbuang percuma, padahal buah jambu air tersebut kaya manfaat. Masyarakat di Perum. Lancang Kuning Sejahtera (LKS) dan Villa Padma memiliki tanaman jambu air di pekarangan rumah yang belum termanfaatkan secara optimal. Masyarakat belum memiliki pengetahuan bagaimana cara memvariasikan pemanfaatan jambu air yang bernilai ekonomis.

Salah satu pemanfaatan jambu air yang bernilai ekonomis adalah dengan membuat nata dari buah jambu air. Nata berupa lapisan putih, kenyal (agak liat), dan padat sebagai hasil penuaian fermentasi oleh mikroba. Selain untuk makanan, nata dapat digunakan untuk pembuatan membran akustik (loudspeaker), karena nata memiliki karakteristik high fibre (Widarto, 2001). Nata dapat dibuat dari bermacam-macam bahan dasar yang biasanya diberi nama sesuai dengan bahan dasarnya. Nata yang dibuat dari air kelapa, buah nanas, buah jambu mete, kedelai, dan buah tomat berturut-turut diberi nama nata de coco, nata de pina, nata de cashew, nata de soya, dan nata de tomato. Selain jenis buah-buahan yang telah disebutkan di atas, buah-buah lainnya yang memungkinkan untuk diolah menjadi nata harus memiliki syarat yaitu buah tersebut cukup banyak mengandung gula atau buah yang manis. Jambu air memiliki kandungan gula pada kulit buahnya yaitu 11,8 gr dan vitamin C 5 mgr (Hardiantono, 1992). Gula yang ada dalam sari buah tersebut dimanfaatkan oleh bakteri Acetobacter xylinum untuk membuat nata (Muchtadi, 1997).

Bakteri Acetobacter xylinum memiliki sensitifitas terhadap sifat fisik adanya getaran yang akan menyebabkan nata yang terbentuk di permukaan cairan menjadi menurun, dan perubahan $\mathrm{pH}$ yang sangat rendah menyebabkan pertumbuhan $A$. xylinum terhambat pertumbuhannya. Akibat yang ditunjukkan oleh terhambatnya pertumbuhan A. xylinum adalah menghasilkan nata lunak dan tipis, atau tidak terbentuknya nata (Rahayu, 1993). Nitrogen anorganik atau organik adalah sumber dalam meningkatkan aktivitas Acetobacter xylinum dalam memproduksi nata. Bahan bisa didapatkan melalui penambahan sumber nitrogen dari luar, yaitu ammonium fosfat (Lapuz dalam Hasnelly, 1997).

Solusi dari permasalahan mitra adalah masyarakat di Perum. Lancang Kuning Sejahtera (LKS) dan Villa Padma diberikan sosialisasi pemanfaatan jambu air menjadi nata de syzygium. Masyarakat diharapkan nantinya dapat mempraktikkan pembuatan nata dari jambu air dan menjadikannya sebagai produk yang dapat dikomersilkan sehingga dapat meningkatkan pendapatan tambahan masyarakat. 


\section{METODE}

Prosedur yang dilakukan dalam kegiatan pengabdian ini terbagi menjadi 2 sesi yang dilakukan selama 1 hari. Sesi pertama berupa seminar tentang pemanfaatan jambu air menjadi nata de syzygium untuk meningkatan pendapatan tambahan masyarakat, kemudian sesi kedua diisi dengan pemutaran video tentang cara membuat nata de syzygium dari jambu air.

\subsection{Kegiatan Sesi 1}

Pada sesi ini, peserta diberikan pembekalan ilmu tentang pemanfaatan jambu air menjadi nata de syzygium untuk meningkatan pendapatan tambahan masyarakat. Sesi 1 ini terdiri dari: penyampaian materi, tanya jawab, dan diskusi. Materi akan disampaikan oleh Ermina Sari, M.Sc. Kegiatan ini dimulai dari pukul 09.00 - 10.00 WIB.

\subsection{Kegiatan Sesi 2}

Pada sesi 2, peserta diberikan tayangan video tentang cara membuat nata de syzygium dari jambu air. Sesi ini dibimbing oleh Jumiati, M.Pd. dan Sri Wahyuni, M.Si. Kegiatan ini dimulai dari pukul 10.00 - 12.00 WIB.

Sebelum kegiatan sesi 1 dimulai dan setelah kegiatan sesi 2 selesai, peserta diberikan pretest dan posttest untuk mengevaluasi tingkat pemahaman peserta.

\section{HASIL DAN PEMBAHASAN}

Pengabdian Kepada Masyarakat yang berjudul "Sosialisasi Manfaat Jambu Air Menjadi Nata de Syzigium untuk Meningkatkan Pendapatan Tambahan Masyarakat Perum. Lancang Kuning Sejahtera (LKS) dan Villa Padma" ini dilakukan pada hari Minggu (21 Juli 2019) di rumah salah satu Tim Pengabdi, yaitu Jumiati, M.Pd. Peserta pelatihan ini sebanyak 15 orang. Narasumber dalam kegiatan ini adalah Ermina Sari, M.Sc., Jumiati, M.Pd., dan Sri Wahyuni, M.Si. yang merupakan Tim Pengabdi.

Pelatihan dilaksanakan mulai pukul 09.00 WIB dan berakhir pada pukul 12.00 WIB. Pelatihan ini dibagi menjadi 2 sesi. Sesi 1 merupakan penyampaian materi mengenai pemanfaatan jambu air menjadi nata de syzygium untuk meningkatan pendapatan tambahan masyarakat. Sesi 1 ini terdiri dari: penyampaian materi, tanya jawab, dan diskusi. Materi disampaikan oleh Ermina Sari, M.Sc. Kegiatan ini dimulai dari pukul 09.00 - 10.00 WIB. Pada awal sesi ini disampaikan kata pembuka acara dari Ketua Tim Pengabdi serta pemberian motivasi mengenai manfaat nyata yang akan didapatkan oleh mitra melalui kegiatan ini. Kemudian diberikan lembar pretest kepada peserta pelatihan untuk mengukur pengetahuan awal peserta mengenai pemanfaatan jambu air menjadi nata de syzygium. Selama sesi 1 ini berlangsung, peserta tampak antusias dalam mengikuti kegiatan. Hal ini dapat dilihat dari tanya jawab dan diskusi mengalir dengan lancar dari peserta kegiatan. Banyak pertanyaan yang diajukan seputar pemanfaatan jambu air dan pembuatan nata.

Setelah kegiatan sesi 1 selesai, dilanjutkan dengan kegiatan sesi 2 yang merupakan pemutaran video tentang cara membuat nata de syzygium dari jambu air. Sesi ini dibimbing oleh Jumiati, M.Pd. dan Sri Wahyuni, M.Si. Kegiatan ini dimulai dari pukul 10.00 - 12.00 WIB. Pada sesi 2 ini peserta terlihat antusias dalam melihat tayangan video tentang cara membuat nata de syzygium dari jambu air. Banyak pertanyaan diajukan peserta terkait pembuatan nata dari jambu air. Setelah kegiatan sesi 2 berakhir, peserta diberi lembar posttest untuk mengevaluasi tingkat pemahaman peserta mengenai materi yang telah didapatkan.

Setelah kegiatan pengabdian selesai, dilakukan pengolahan data pretest dan posttest. Berikut disajikan hasil prestest dan posttest: 
Tabel 1. Hasil Pretest Masyarakat Perum. Lancang Kuning Sejahtera (LKS) dan Masyarakat Perum. Villa Padma

\begin{tabular}{clccc}
\hline No. & \multicolumn{1}{c}{ Soal/ Pertanyaan } & Tahu & Tidak Tahu \\
\hline 1 & $\begin{array}{l}\text { Pengetahuan tentang } \\
\text { mengkonsumsi jambu air }\end{array}$ & manfaat & $66,66 \%$ & $33,34 \%$ \\
\hline 2 & $\begin{array}{l}\text { Pengetahuan tentang } \\
\text { mengkonsumsi nata }\end{array}$ & manfaat & $33,33 \%$ & $66,67 \%$ \\
\hline 3 & $\begin{array}{l}\text { Pengetahuan tentang bahan-bahan yang } \\
\text { digunakan untuk membuat nata dari jambu } \\
\text { air }\end{array}$ & $0 \%$ & $100 \%$ \\
\hline 4 & $\begin{array}{l}\text { Pengetahuan tentang cara membuat nata } \\
\text { dari jambu air }\end{array}$ & $0 \%$ & $100 \%$ \\
\hline 5 & $\begin{array}{l}\text { Pengetahuan tentang peluang } \\
\text { pengkomersilan nata de syzigium }\end{array}$ & $0 \%$ & $100 \%$ \\
\hline
\end{tabular}

Berdasarkan hasil pretest di atas diketahui bahwa 33,34 \% peserta tidak mengetahui manfaat mengkonsumsi jambu air, 66,67 \% peserta tidak mengetahui manfaat mengkonsumsi nata, $100 \%$ peserta tidak mengetahui bahan-bahan yang digunakan untuk membuat nata dari jambu air, $100 \%$ peserta tidak mengetahui cara membuat nata dari jambu air, dan $100 \%$ peserta tidak mengetahui peluang pengkomersilan nata de syzigium. Rerata nilai pretest adalah 19,99 atau $20 \%$. Dari hasil tersebut dapat disimpulkan bahwa peserta tidak memiliki pengetahuan awal mengenai bahan-bahan yang digunakan untuk membuat nata dari jambu air, cara membuat nata dari jambu air, hingga peluang pengkomersilan nata de syzigium dan hanya sebahagian kecil yang mengetahui manfaat mengkonsumsi jambu air dan nata, sehingga kegiatan pengabdian ini memang diperlukan oleh Masyarakat Perum. Lancang Kuning Sejahtera (LKS) dan Villa Padma.

Tabel 2. Hasil Posttest Masyarakat Perum. Lancang Kuning Sejahtera (LKS) dan Masyarakat Perum. Villa Padma

\begin{tabular}{clccc}
\hline No. Soal/ Pertanyaan & Tahu & Tidak Tahu \\
\hline 1 & $\begin{array}{l}\text { Pengetahuan } \begin{array}{c}\text { mentang } \\
\text { mengkonsumsi jambu air }\end{array} \\
\text { mengat tentang }\end{array}$ & $\begin{array}{l}\text { Pengetahuan manfaat } \\
\text { mengkonsumsi nata }\end{array}$ & $100 \%$ & $0 \%$ \\
\hline 3 & $\begin{array}{l}\text { Pengetahuan tentang bahan-bahan yang } \\
\text { digunakan untuk membuat nata dari jambu } \\
\text { air }\end{array}$ & $100 \%$ & $0 \%$ \\
\hline 4 & $\begin{array}{l}\text { Pengetahuan tentang cara membuat nata } \\
\text { dari jambu air }\end{array}$ & $100 \%$ & $0 \%$ \\
\hline 5 & $\begin{array}{l}\text { Pengetahuan tentang peluang } \\
\text { pengkomersilan nata de syzigium }\end{array}$ & $100 \%$ & $0 \%$ \\
\hline
\end{tabular}

Berdasarkan hasil posttest di atas diketahui bahwa $100 \%$ peserta sudah mengetahui manfaat mengkonsumsi jambu air dan nata, bahan-bahan yang digunakan untuk membuat nata dari jambu air, cara membuat nata dari jambu air, hingga peluang pengkomersilan nata de syzigium. Rerata nilai posttest adalah 100 atau $100 \%$. Dari hasil tersebut dapat disimpulkan bahwa peserta mengikuti kegiatan sosialisasi dengan baik, sehingga terdapat peningkatan pengetahuan akhir setelah mengikuti seluruh sesi kegiatan sosialisasi. 


\section{KESIMPULAN}

Berdasarkan hasil kegiatan sosialisasi yang telah dilakukan dapat disimpulkan kegiatan sosialisasi dapat meningkatkan wawasan peserta terkait manfaat mengkonsumsi jambu air dan nata, bahan-bahan yang digunakan untuk membuat nata dari jambu air, cara membuat nata dari jambu air, hingga peluang pengkomersilan nata de syzigium.

\section{DAFTAR PUSTAKA}

Hanifa, Millati, H., \& Haryanti, S. (2016). Morfoanatomi Daun Jambu Air (Syzygium samarangense) var. Demak Normal dan Terserang Hama Ulat. Ejournal2.undip.ac.id, Vol. 1 No. 1.

Hardiantono, B. (1992). Pedoman Praktis Budidaya Tanaman Jambu. PD Mahkota: Jakarta.

Hariyanto, B. (1992). Jambu Air. Penebar Swadaya: Jakarta.

Hasnelly, Sumartini, Dewi. (1997). Mempelajari Pengaruh Penambahan Konsentrasi Sacharomyces cereviceae dan Ammonium Fosfat pada Pembuatan Nata Kulit Nenas. Prosiding Seminar Teknologi Pangan.

Muchtadi, T. R. (1997). Petunjuk Laboratorium Teknologi Proses Pengolahan Pangan. PAU Pangan dan Gizi IPB: Bogor.

Rahayu, E. S. (1993). Bahan Pangan Hasil Fermentasi. Pusat Antar Universitas Pangan dan Gizi UGM: Yogyakarta.

Rukmana, R. 1997. Jambu Air (Tabulampot). Kanisius: Yogyakarta.

Tirtawanata, T. C. (1999). Makanan dalam Perspektif Al-Qur'an dan Ilmu Gizi. Balai Penerbit FKUI: Jakarta.

Wahyuni, S., Sari, M., \& Afidah, M. 2017. Sosialisasi dan Pelatihan Teknik Penyaringan Air di Desa Mengkapan, Siak. Dinamisia: Jurnal Pengabdian Kepada Masyarakat, Vol 1 No 1 (2017), 100105.

Widarto. (2001). Teknologi Tepat Guna. Disampaikan pada pembekalan mahasiswa peserta KKN Universitas Negeri Yogyakarta. 